\title{
Biofield Energy Therapy: Role in Multiple Organ Health Specific Biomarkers in Cell-Based Assay
}

\author{
Sakina Aleemah Ansari1, Mahendra Kumar Trivedi1 ${ }^{1}$, Alice Branton¹, \\ Dahryn Trivedi ${ }^{1}$, Gopal Nayak ${ }^{1}$, Mayank Gangwar ${ }^{2}$ and Snehasis \\ Jana $^{2 *}$ \\ ${ }^{1}$ Trivedi Global, Inc., Henderson, Nevada, USA \\ ${ }^{2}$ Trivedi Science Research Laboratory Pvt. Ltd., Thane-West, Maharashtra, India
}

\section{Research Article}

Volume 2 Issue 2

Received Date: June 20, 2019

Published Date: July 23, 2019

DOI: $10.23880 /$ aabsc- 16000136

*Corresponding author: Snehasis Jana, Trivedi Science Research Laboratory Pvt. Ltd., Thane-West, Maharashtra, India, Email: publication@trivedieffect.com

\section{Abstract}

The major cause of high rate of mortality is the multiple organ dysfunction among critical care healthcare services. The aim of the current study was to evaluate the impact of the Biofield Energy Treated test formulation using standard and specific cell lines related with vital organs functioning. The test formulation and the specific cell media was divided into two parts; one part was untreated (UT) and other part received the Biofield Energy Treatment remotely by a renowned Biofield Energy Healer, Sakina Aleemah Ansari, USA and labeled as the Biofield Energy Treated (BT) test formulation/media. The test formulation was tested against various activities using cell line assay in their specific medium (Med). The test formulation was tested for cell viability, and the results showed that the test formulation at tested concentrations was found safe and non-toxic. Cytoprotective activity showed improved cellular restoration by 105.4\% (at $25 \mu \mathrm{g} / \mathrm{mL}$ ), 32.8\% (at $25 \mu \mathrm{g} / \mathrm{mL}$ ), and 151.8\% (at $10 \mu \mathrm{g} / \mathrm{mL}$ ) in the UT-Med + BT-TI, BT-Med + UT-TI, and BTMed + BT-TI groups respectively, as compared to the untreated test group in the human cardiac fibroblasts cells (HCF) cells, while improved restoration of cell viability by $22.4 \%$ (at $25.5 \mu \mathrm{g} / \mathrm{mL}$ ), $67.1 \%$ (at $10 \mu \mathrm{g} / \mathrm{mL}$ ), and $72.9 \%$ (at 10 $\mu \mathrm{g} / \mathrm{mL}$ ) in the UT-Med + BT-TI, BT-Med + UT-TI, and BT-Med + BT-TI groups respectively, as compared to the untreated test group in HepG2 cells. Cellular restoration in A549 cells was improved by $9.3 \%, 70.4 \%$, and $14.1 \%$ at $0.1,1$, and 25.5 $\mu \mathrm{g} / \mathrm{mL}$ respectively, in the BT-Med + UT-TI group, while $3 \%$ and $4.6 \%$ improved cellular restoration was reported at 10 and $25.5 \mu \mathrm{g} / \mathrm{mL}$ respectively, at BT-Med + BT-TI groups as compared to the untreated test group. ALP activity in Ishikawa cells was significantly increased by $68.4 \%, 41.1 \%$, and $18.8 \%$ at $0.1,10$, and $50 \mu \mathrm{g} / \mathrm{mL}$ respectively, in the UT-Med + BTTI group, while in MG-63 cells showed maximum increased ALP activity by $92.7 \%, 84.5 \%$, and $93.2 \%$ respectively in the UT-Med + BT-TI, BT-Med + UT-TI, and BT-Med + BT-TI group respectively, at $50 \mu \mathrm{g} / \mathrm{mL}$ as compared to the untreated group. The maximum percent cellular protection of HCF (heart) cells (decreased of LDH activity) was significantly 
increased by 51.6\%, 88.7\%, and 53.7\% in the UT-Med + BT-TI, BT-Med + UT-TI, and BT-Med + BT-TI groups respectively, at $10 \mu \mathrm{g} / \mathrm{mL}$ as compared to the untreated group. Alanine amino transferase (ALT) activity was reported in terms of percent cellular protection of HepG2 (liver) cells. The test data showed improved HepG2 cells protection (represents decreased ALT activity) by 33\%, 90.2\%, and 72.1\% in the UT-Med + BT-TI, BT-Med + UT-TI, and BT-Med + BT-TI groups respectively, at $25 \mu \mathrm{g} / \mathrm{mL}$ as compared to the untreated test group. Percentage cellular protection of A549 (lungs) cells (represents increased of SOD activity) was increased by $21.5 \%$ at $25.5 \mu \mathrm{g} / \mathrm{mL}$ in the UT-Med + BT-TI, while $33.4 \%$, $25.8 \%$, and $21.5 \%$ at 1,10 , and $25.5 \mu \mathrm{g} / \mathrm{mL}$ respectively, in the BT-Med + UT-TI group, and $12.8 \%$ increased SOD activity at $25.5 \mu \mathrm{g} / \mathrm{mL}$ in the BT-Med + BT-TI groups as compared to the untreated group. Serotonin level was significantly increased 137.4\% (at $0.1 \mu \mathrm{g} / \mathrm{mL}$ ), 65.4\% (at $0.1 \mu \mathrm{g} / \mathrm{mL}$ ), and 77.3\% (at $10 \mu \mathrm{g} / \mathrm{mL}$ ) in the UT-Med + BT-TI, BT-Med + UTTI, and BT-Med + BT-TI groups, respectively compared to untreated test group in human neuroblastoma cells (SH-SY5Y). However, the relative quantification (RQ) of vitamin D receptor (VDR) was significantly increased by $24.2 \%($ at $1 \mu \mathrm{g} / \mathrm{mL}$ ), 213.7\% (at $10 \mu \mathrm{g} / \mathrm{mL}$ ), and 328.7\% (at $10 \mu \mathrm{g} / \mathrm{mL}$ ) in the UT-Med + BT-TI, BT-Med + UT-TI, and BT-Med + BT-TI groups, respectively as compared to the untreated in MG-63 cells. Thus, the data concluded that The Trivedi Effect ${ }^{\circledR}$ would be significantly useful for improving multiple organs health, which can be used for many coronary artery diseases, arrhythmias, congenital heart disease, cardiomyopathy, cirrhosis, liver cancer, hemochromatosis, asthma, chronic bronchitis, cystic fibrosis, osteoporosis, etc.

Keywords: The Trivedi Effect ${ }^{\circledR}$; Biofield Energy Treatment; Organ health; Multiple organ failure; Bone health

\section{Introduction}

Herbal based nutraceutical products with selected phytonutrients continue to expand rapidly across the world against treatment of various health challenges among the national healthcare settings [1]. It was observed that the use of complementary and alternative medicines has witnessed a tremendous acceptance among the public and diverted their interest in natural therapies in developing as well as developed countries. More than four billion people in the developing world supports the use of herbal based medicinal therapies, which is one of the primary sources of healthcare and traditional medical practice in various communities [2]. Along with herbal based medicinal products, major supplements such as vitamins, minerals along with many alternative treatment approaches have been found to have significant role in therapeutic approach. The reason for acceptance of these formulations is the minimal or no adverse effects compared with the synthetic drug moieties. Synthetic drugs affect the immune system and results in overall quality of life. It also affects the organs and their functions which results in multiorgan failure. However, there is no such novel herbal-based test formulation that can improve the overall organ health using cell based standard assays. Thus, a novel test formulation has been developed that would improve the overall functioning of multiple organs using standard cell line based bioassay. With this respect, the novel test formulation was designed on the basis of best scientific literature, which is the combination of herbal products viz. panax ginseng extract and beta carotene, minerals viz. calcium chloride, magnesium gluconate, zinc chloride, sodium selenate, ferrous sulfate, and vitamins viz. vitamin $B_{12}$, vitamin $D_{3}$, ascorbic acid, and vitamin $\mathrm{B}_{6}$. This formulation is designed for overall functioning of the organs that can results in improved overall health conditions against many pathological conditions such as lung disorder, liver disorder, breast cancer, liver cancer, aging, muscle damage, and overall health. Minerals and vitamins present in the test formulation provide significant functional support to all the vital organs [3-5]. Panax ginseng has significant capacity to improve mental, physical abilities, cognitive health, and is defined as the potent immunomodulator [6,7]. The test formulation was tested against many cell lines and was evaluated for biological activities such as bone health parameters using MG-63 cells, lung health parameter using A549 cells, liver health parameter using HepG2 cells, heart health parameter using Human Cardiac fibroblasts, and neuronal health parameter using SH-SY5Y cells [8-17]. In addition, the test formulation and the cell line specific media was 
treated with the complementary medicine i.e. Biofield Energy Treatment by a renowned Biofield Energy Healer.

Biofield Energy as a Complementary and Alternative Medicine (CAM) includes both putative and subtle energy fields that have the ability to regulate the living organisms homeodynamic function's along with a substantial role in perceptive and guiding various health processes [18]. Besides, many outstanding results have been reported worldwide with the cancer science application of Biofield Energy Healing Treatment $[19,20]$. Human Biofield Energy is recently reported that it is capable of suppression of mouse lung carcinoma growth besides significant immune function and anti-inflammatory activity [21]. Thus, Biofield Energy Healing therapies have gained popularity because of improved immunological response, while its current status and future perspectives has been reported worldwide [22]. Besides, CAM therapies have been recommended by The National Center for Complementary/Alternative Medicine (NCCAM) and there therapies exist in various therapies such as external qigong, Johrei, Reiki, therapeutic touch, yoga, Qi Gong, polarity therapy, Tai Chi, pranic healing, deep breathing, chiropractic/osteopathic manipulation, guided imagery, meditation, massage, homeopathy, hypnotherapy, progressive relaxation, acupressure, acupuncture, special diets, relaxation techniques, Rolfing structural integration, healing touch, movement therapy, pilates, mindfulness, Ayurvedic medicine, traditional Chinese herbs and medicines in biological systems $[23,24]$. The Trivedi Effect $^{\circledR}{ }^{\circledR}$-Consciousness Energy Healing therapies have been widely accepted and popular worldwide healing approach with significant results in many scientific field. The Trivedi Effect ${ }^{\circledR}$ has been reported with significant results in the metal physicochemical properties, agriculture science, microbiology, biotechnology, and changed bioavailability of many compounds, skin health, nutraceuticals, cancer science research, improved bone health, human health and wellness [25-40]. Due to the continued clinical and preclinical applications of Biofield Energy Healing Treatments, the test formulation was studied for impact of the Biofield Energy Healing Treated test formulation on the function of vital organs such as bones, heart, liver, lungs, and brain specific biomarkers in different cell-lines.

\section{Materials and Methods}

\section{Chemicals and Reagents}

Chemicals such as panax ginseng extract were obtained from panacea Phytoextracts, India. Sodium selenate and ascorbic acid were obtained from Alfa Aesar, India. Quercetin was purchased from Clearsynth, India, while silymarin and curcumin were obtained from Sanat Chemicals, India. Ferrous sulfate, vitamin $B_{6}$, vitamin $D_{3}$, vitamin $B_{12}$, calcium chloride, naringenin, trimetazidine (TMZ), 3-(4,5-Dimethylthiazol-2-yl)-2,5Diphenyltetrazolium Bromide (MTT), and ethylenediaminetetraacetic acid (EDTA) were procured from Sigma Chemical Co. (St. Louis, MO). Zinc chloride, magnesium gluconate, $\beta$-carotene, and calcitriol were purchased from TCI chemicals, Japan. Reverse Transcription Kit, RNeasy Mini Kit, and Syber Green PCR kits were procured from Qiagen, India. All the other chemicals used in this experiment were analytical grade procured from India.

\section{Biofield Energy Healing Treatment}

Biofield Energy Healing Treatment was performed on the test formulation and the specific cell line medium. Eleven ingredients combination were used for the test formulation such as panax ginseng extract, $\beta$-carotene, zinc chloride, calcium chloride, magnesium gluconate, sodium selenate, ferrous sulfate, ascorbic acid, vitamin $\mathrm{B}_{12}$, vitamin $\mathrm{D}_{3}$, and vitamin $\mathrm{B}_{6}$. The test formulation and the medium were divided into two parts, one portion was considered as the untreated group, where no Biofield Energy Treatment was provided (UT-TI and UT-Med). Further, the untreated group was treated with a "sham" healer for comparison purposes, who did not have any knowledge about the Biofield Energy Healing Treatment. Another test formulation portion and the medium received the Biofield Energy Treatment (The Trivedi Effect ${ }^{\circledR}$ ) remotely by Sakina Aleemah Ansari under standard laboratory conditions for $\sim 3$ minutes through healer's unique Biofield Energy Transmission process and were referred as the Biofield Energy Treated formulation (BT-TI) and Biofield Energy Treated medium (BT-Med). The Biofield Energy Healer was located in the USA, however the test formulation constituents were located in the research laboratory of Dabur Research Foundation, New Delhi, India. Biofield Energy Healer in this experiment did not visit the laboratory, nor had any contact with the test sample and the medium. After that, the Biofield Energy Treated and untreated test items were kept in similar sealed conditions and used for the study as per the study plan.

\section{Cell Viability Testing using MTT Assay}

All the experimental cells used in this study were counted for cell viability using hemocytometer in 96-well plates at the specific density as mentioned in the Table 1. The cells were then incubated overnight under standard growth conditions to allow cell recovery and exponential growth. Following overnight incubation, cells were treated with different concentrations of test formulations 
(BT/UT). After respective treatments, the cells were incubated in a $\mathrm{CO}_{2}$ incubator at $37^{\circ} \mathrm{C}, 5 \% \mathrm{CO}_{2}$, and $95 \%$ humidity. After incubation, the plates were taken out and $20 \mu \mathrm{L}$ of $5 \mathrm{mg} / \mathrm{mL}$ of MTT 3-(4,5-dimethylthiazol-2-yl)2,5-diphenyl tetrazolium bromide solution was added to all the wells followed by additional incubation for 3 hours at $37^{\circ} \mathrm{C}$. The supernatant was aspirated and $150 \mu \mathrm{L}$ of DMSO was added to each well to dissolve formazan crystals. The absorbance of each well was read at $540 \mathrm{~nm}$ using Synergy HT microplate reader. The percentage cytotoxicity at each tested concentration was calculated using Equation 1:

$\%$ Cytotoxicity $=[(\mathrm{R}-\mathrm{X}) / \mathrm{R}] * 100$.

Where, $\mathrm{X}=$ Absorbance of treated cells; $\mathrm{R}=$ Absorbance of untreated cells

The concentrations exhibiting percentage cytotoxicity $<30 \%$ was considered as non-cytotoxic [41].

\begin{tabular}{|c|c|c|c|}
\hline S. No. & Cell Line & Plating & Time Point \\
\hline 1 & MG-63 (Bone) & $3 \times 10^{4}$ cells/ well, 96-well plate & 5 days \\
\hline 2 & Ishikawa (Uterus) & $3 \times 10^{4}$ cells/ well, 96-well plate & 5 days \\
\hline 3 & A549 (Lung) & $10 \times 10^{4}$ cells/ well, 96-well plate & 24 hours \\
\hline 4 & HepG2 (Liver) & $1 \times 10^{4}$ cells/ well, 96-well plate & 24 hours \\
\hline 5 & $\begin{array}{c}\text { Human Cardiac fibroblasts } \\
\text { (Heart) }\end{array}$ & $1 \times 10^{4}$ cells/ well, 96-well plate & 24 hours \\
\hline 6 & SH-SY5Y (Neuronal cell) & $10 \times 10^{4}$ cells/ well, 96-well plate & 24 hours \\
\hline
\end{tabular}

Table 1: Information related to six cell lines with their plating density and time-point.

\section{Cytoprotective Action of the Test Formulation}

Cytoprotective effect was evaluated on the human cardiac fibroblasts-HCF; human hepatoma cells-HepG2; and adenocarcinomic human alveolar basal epithelial cells-A549. These cells were counted and plated in suitable medium followed by overnight incubation. The cells were then treated with the test items/positive control at the non-cytotoxic concentrations for 24 hours. After 24 hours, the oxidative stress using $10 \mathrm{mM} t$-BHP for 3.5 hours was given to the cells. The cells treated with $10 \mathrm{mM}$ of $t$-BHP alone served as negative control. After 3.5 hours of incubation with $t$-BHP the above plates were taken out and cell viability was determined by MTT assay. The percentage protection corresponding to each treatment was calculated using equation 2 :

$\%$ Protection $=\left[\left(\right.\right.$ Absorbance $_{\text {sample }}-$ Absorbance $\left.\left._{\mathrm{t}-\mathrm{BHP}}\right)\right] * 100 /$ [Absorbance untreated Absorbance t_BHP $_{\text {B }}$...

\section{Estimation of Alkaline Phosphatase (ALP) activity}

ALP was estimated in two cells viz. human bone osteosarcoma cells-MG-63 and human endometrial adenocarcinoma cells-Ishikawa, which were counted using a hemocytometer and plated in 24-well plates at the density corresponding to $1 \times 10^{4}$ cells/well in phenol-free DMEM supplemented with $10 \%$ CD-FBS. After the respective treatments, the cells in the above plate were incubated for 48 hours in $\mathrm{CO}_{2}$ incubator at $37^{\circ} \mathrm{C}, 5 \% \mathrm{CO}_{2}$, and $95 \%$ humidity. After 48 hours of incubation, the plates were taken out and processed for the measurement of ALP enzyme activity. The cells were washed with $1 \mathrm{X}$ PBS and lysed by freeze-thaw method i.e., incubation at $80^{\circ} \mathrm{C}$ for 20 minutes followed by incubation at $37^{\circ} \mathrm{C}$ for 10 minutes. To the lysed cells, $50 \mu \mathrm{L}$ of substrate solution i.e.5 $\mathrm{mM}$ of $p$-nitrophenyl phosphate ( $p \mathrm{NPP}$ ) in $1 \mathrm{M}$ diethanolamine and $0.24 \mathrm{mM}$ magnesium chloride $\left(\mathrm{MgCl}_{2}\right)$ solution ( $\left.\mathrm{pH} 10.4\right)$ was added to all the wells followed by incubation for 1 hour at $37^{\circ} \mathrm{C}$. The absorbance was measured at $405 \mathrm{~nm}$ using Synergy HT microplate reader (Biotek, USA). The absorbance values were obtained and normalized with substrate blank ( $p$ NPP solution alone) absorbance values. The percentage increase in ALP enzyme activity with respect to the untreated cells (baseline group) was calculated using Equation 3:

\% Increase in ALP $=\{(X-R) / R\}^{*} 100----------------(3)$ Where, $\quad \mathrm{X}=$ Absorbance of cells corresponding to positive control and test groups

$\mathrm{R}=$ Absorbance of cells corresponding to baseline group (untreated cells)

\section{Estimation of Lactate Dehydrogenase (LDH) in Human Cardiac Fibroblasts (HCF) Cells}

HCF cells were used for the estimation of LDH activity. The cells were counted and plated at the density of $0.25 \mathrm{X}$ $10^{6}$ cells/ well in 24-well plates in cardiac fibroblast specific mediumfollowed by overnight incubation. The cells were then treated with the test formulation combinations/positive control at the non-cytotoxic 
concentrations for 24 hours. After 24 hours, oxidative stress was given to the cells using $10 \mathrm{mM} t$-BHP for 3.5 hours. The untreated cells were served as control group, which did not receive any treatment and were maintained in cell growth medium only. The cells were treated with $10 \mathrm{mM}$ of $t$-BHP alone served as the negative control. After 3.5 hours of incubation with $t$-BHP, the above plates were taken out and LDH activity was determined using LDH activity kit as per manufacturer's instructions. The percent increase in LDH activity was calculated using equation 4 .

$\%$ Increase $=[(\mathrm{LDH} \text { activity } \text { sample }-\mathrm{LDH} \text { activityt-BHP })]^{* 100 /}$ [LDH activity untreated LDH activity $\_$BHP].

\section{Estimation of ALT in Liver Cells (HepG2)}

The human hepatoma cells (HepG2) were used for the estimation of ALT activity. The cells were counted and plated at the density of $5 \times 10^{4}$ cells/well in 48-well plates in DMEM media followed by overnight incubation. The cells were then treated with the test formulation/positive control at the non-cytotoxic concentrations for 24 hours. After 24 hours, oxidative stress was given to the cells using $400 \mu \mathrm{M} t$-BHP for 3.5 hours. The untreated cells served as control that did not receive any treatment and were maintained in cell growth medium only. Cells treated with $400 \mu \mathrm{M}$ of $t$-BHP alone served as negative control. After 3.5 hours of incubation with $t$-BHP, the above plates were taken out and ALT activity was determined using ALT activity kit as per manufacturer's instructions. The percent increase in ALT activity was calculated using equation 5 .

$\%$ Increase $=[(\text { ALT activity } \text { sample }- \text { ALT activityt-BHP })]^{* 100 /}$ [ALT activity untreated ${ }^{-A L T}$ activity t_BHP] $_{\text {B }}$

\section{Estimation of Superoxide Dismutase (SOD) in Lung (A549) Cells}

The adenocarcinomic human alveolar basal epithelial cells (A549) were used for the estimation of SOD activity. The A549 cells were counted and plated at the density of $1 \mathrm{X} 10^{4}$ cells/well in 24-well plates in DMEM followed by overnight incubation. The cells were then treated with the test formulation/positive control at the non-cytotoxic concentrations along with $100 \mu \mathrm{M} t$-BHP to induce oxidative stress. The untreated cells served as control that did not receive any treatment and were maintained in cell growth medium only. Cells treated with $100 \mu \mathrm{M}$ of $t$-BHP alone served as negative control. After 24 hours of incubation with $t$-BHP the above plates were taken out and SOD activity was determined using SOD activity kit as per manufacturer's instructions. The percent increase in SOD activity was calculated using equation 6 :

$\%$ Increase in SOD activity $=((\mathrm{X}-\mathrm{R}) / \mathrm{R}) * 100$.

Where, $\mathrm{X}=\mathrm{SOD}$ activity corresponding to test item or positive control

$\mathrm{R}=\mathrm{SOD}$ activity corresponding to the control group.

\section{Estimation of Serotonin in Neuronal Cells (SH- SY5Y)}

The human neuroblastoma (SH-SY5Y) cells were used for the estimation of serotonin level. The cells were counted and plated at the density of $10 \times 10^{4}$ cells/well in 96-well plates followed by overnight incubation. The cells were then treated with the test formulation/positive control at the non-cytotoxic concentrations. The untreated cells served as control that did not receive any treatment and were maintained in cell growth medium only. The treated cells were incubated for 24 hours. Serotonin release was determined by ELISA as per manufacturer's protocol. The percent increase in serotonin levels was calculated using equation 7 -

$$
[(\mathrm{X}-\mathrm{R}) / \mathrm{R}] * 100 \text {. }
$$

Where, $\mathrm{X}=$ Serotonin levels corresponding to test item or positive control,

$\mathrm{R}=$ Serotonin levels corresponding to control group.

\section{Effect of Test Formulation on Vitamin D Receptor (VDR) in Bone (MG-63) Cells}

The effect of test formulation on vitamin D receptor (VDR) activity in bone (MG-63) cells were counted using the hemocytometer at density $2 \times 10^{5}$ cells/well in 6-well plates followed by overnight incubation. The cells were then sera starved for 24 hours and treated with the test formulation/positive control at the non-cytotoxic concentrations, while control group did not receive any treatment, which were maintained in cell growth medium only. The treated cells were incubated for 24 hours and VDR expression was determined by qPCR using VDR specific primers. Cells were harvested by scrapping and washed with PBS. Cell pellets obtained were analyzed for VDR gene expression using human VDR specific primers: Forward: 5'-GCTGACCTGGTCAGTTACAGCA-3', Reverse: 5'-CACGTCACTGACGCGGTACTT-3'.VDR gene expression was normalized using House-keeping (HK) reference. Relative quantification (RQ) of VDR gene in Biofield Energy Treated cells was calculated with respect to the untreated cells using equation 8 : 
$\mathrm{RQ}=2-\mathrm{N}$

Where, $\mathrm{N}$ is the relative Threshold Cycle $\left(\mathrm{C}_{\mathrm{T}}\right)$ value of treated sample with respect to the untreated sample.

\section{Statistical Analysis}

All the experimental values were presented as mean \pm SD (standard deviation) of three independent experiments. The statistical analysis was performed using SigmaPlot statistical software (v11.0). For two group comparison, student's $t$-test was used. For multiple group comparison, one-way analysis of variance (ANOVA) was used followed by post-hoc analysis by Dunnett's test. Statistically significant values were set at the level of $p \leq 0.05$.

\section{Results and Discussion}

\section{Cell Viability using MTT Assay}

MTT assay for cell viability testing was used in each cell lines for testing the safe concentrations of test formulation. The concentrations of the test formulation were found safe on the basis of percentage of cell viability data. The criteria for selection of non-cytotoxic test formulation concentration and the positive controls were found to be less than $30 \%$ cytotoxicity or greater than $70 \%$ cell viability. All the results were considered and represented as safe and non-cytotoxic concentrations. The experimental data suggested that the overall percent cell viability in different cell-lines viz. MG-63, Ishikawa, A549, HepG2, HCF, and SH-SY5Y were found safe, which were tested for other activities.

\section{Evaluation of Cytoprotective Effect of the Test Formulation}

Cytoprotective activity of the test formulation was screened against three cell lines viz. HCF, HepG2, and A549 cells. The results were presented in terms of percentage cellular protection against $t$-BHP induced cell damage (Figure 1). Cytoprotective activity in the cell line based assay after induction of oxidative stress using tertbutyl hydroperoxide ( $t$-BHP) is considered as the gold standard [41,42]. Trimetazidine (TMZ) was used as a positive control group in human cardiac fibroblasts cells (HCF) for cytoprotective effect which showed significant restoration of cell viability by $48 \%, 57.2 \%$, and $87.2 \%$ at 5,10 , and $25 \mu \mathrm{g} / \mathrm{mL}$, respectively as compared to the $t$ -
BHP induced group. Besides, the restoration of cell viability among the tested groups by the test formulation was reported as $59.5 \%$ and $105.4 \%$ at 10 and $25 \mu \mathrm{g} / \mathrm{mL}$ respectively, in the UT-Med + BT-TI group, while $32.8 \%$ improved cellular restoration at $25 \mu \mathrm{g} / \mathrm{mL}$ in the BT-Med + UT-TI, and $151.8 \%$ and $97.4 \%$ improved cellular restoration at 10 and $25 \mu \mathrm{g} / \mathrm{mL}$ respectively, in the BTMed + BT-TI group as compared to the untreated test group (UT-Med + UT-TI group). Similarly, silymarin was used as positive control in HepG2 cells, which resulted in significant cellular restoration by $40 \%, 65.9 \%$, and $86.6 \%$ at 5,10 and $25 \mu \mathrm{g} / \mathrm{mL}$ respectively, as compared to the $t$ BHP induced group. Besides, the test formulation showed maximum restoration of cell viability by $6.1 \%$ and $22.4 \%$ at 0.1 and $25.5 \mu \mathrm{g} / \mathrm{mL}$ respectively, in the UT-Med + BT-TI group, while $54.6 \%$ and $67.1 \%$ improved cellular restoration at 1 and $10 \mu \mathrm{g} / \mathrm{mL}$ respectively, in the BT-Med + UT-TI, and 55.1\%, 72.9\%, and 6.7\% improved cellular restoration at $0.1,10$ and $25.5 \mu \mathrm{g} / \mathrm{mL}$ respectively, in the BT-Med + BT-TI group as compared to the untreated test group (UT-Med + UT-TI group). In addition, quercetin was used as positive control in adenocarcinomic human alveolar basal epithelial cells (A549) resulted, restoration of cell viability by $47.3 \%, 56.8 \%$, and $66.4 \%$ at 5,10 and $25 \mu \mathrm{g} / \mathrm{mL}$, respectively compared to the $t$-BHP induced group. Besides, the test formulation showed maximum restoration of cell viability by $1.6 \%$ at $10 \mu \mathrm{g} / \mathrm{mL}$ in the UT-Med + BT-TI group, while 9.3\%, 70.4\%, and $14.1 \%$ increased cell viability at $0.1,1$, and $25.5 \mu \mathrm{g} / \mathrm{mL}$ respectively in the BT-Med + UT-TI group. Similarly, $3 \%$ and $4.6 \%$ improved cellular restoration was reported at 10 and $25.5 \mu \mathrm{g} / \mathrm{mL}$ respectively, at BT-Med + BT-TI groups as compared to the UT-Med + UT-TI group. Cytoprotection action is directly correlated with the protection of cells against injuries due to stress and free radicals [43,44]. This cell damage is one of the leading causes of immune related disorders such as cardiovascular diseases, aging, cancer, diabetes, and many more [45-47]. Overall, it can be assumed cellular restoration was achieved due to Biofield Energy Treatment (The Trivedi Effect ${ }^{\circledR}$ ) after induction of $t$-BHP induced oxidative stress against the HCF, HepG2, and A549 cells with respect to the cardiotoxicity, hepatotoxicity, and lung cell toxicity. Therefore, the Biofield Energy Healing Treatment could be used against many pathological etiologies such as cardiovascular, liver, and lung diseases. 


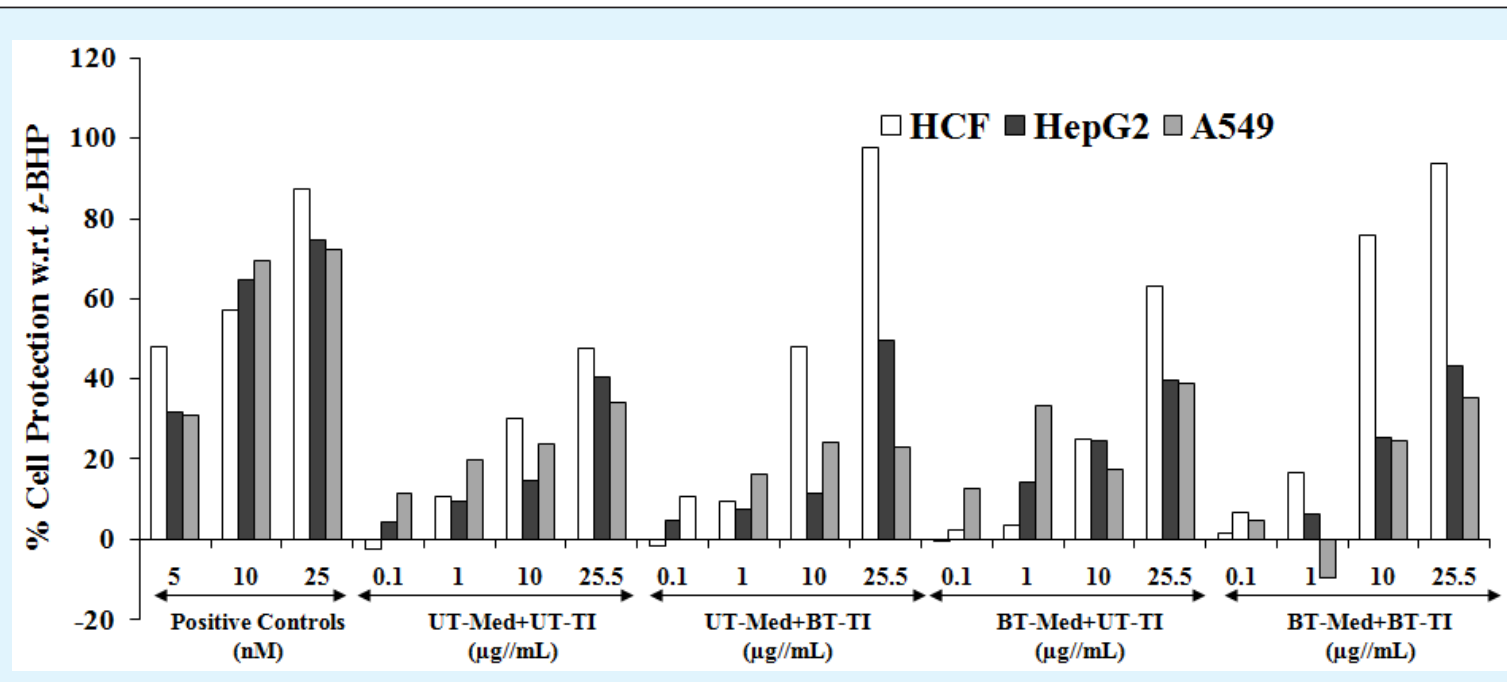

Figure 1: Cytoprotective action of the test formulation in human cardiac fibroblasts cells (HCF), human hepatoma cells (HepG2), and adenocarcinomic human alveolar basal epithelial cells (A549) against tert-butyl hydroperoxide ( $t$ BHP) induced damage. Trimetazidine $(\mu \mathrm{M})$, silymarin $(\mu \mathrm{g} / \mathrm{mL})$, and quercetin $(\mu \mathrm{M})$ were used as positive control in HCF, HepG2, and A549 cells, respectively. UT: Untreated; Med: Medium; BT: Biofield Treated; TI: Test item.

\section{Estimation of Alkaline Phosphatase (ALP) Activity}

ALP is one of the important bone health biomarker, it correlation has been reported in controlling various bone disorders [48,49] such as low bone density and osteoporosis, osteogenesis imperfect and Paget's disease, which makes bones brittle. ALP activity was evaluated against two cell lines, MG-63 and Ishikawa cells after treatment with the test formulation. Naringenin (nM) was used as positive control in Ishikawa cells, and the results suggested significant increased ALP level by $18.3 \%$, $35.8 \%$, and $109.4 \%$ at $0.1,1$, and $10 \mathrm{nM}$ respectively as presented in the Figure 2.

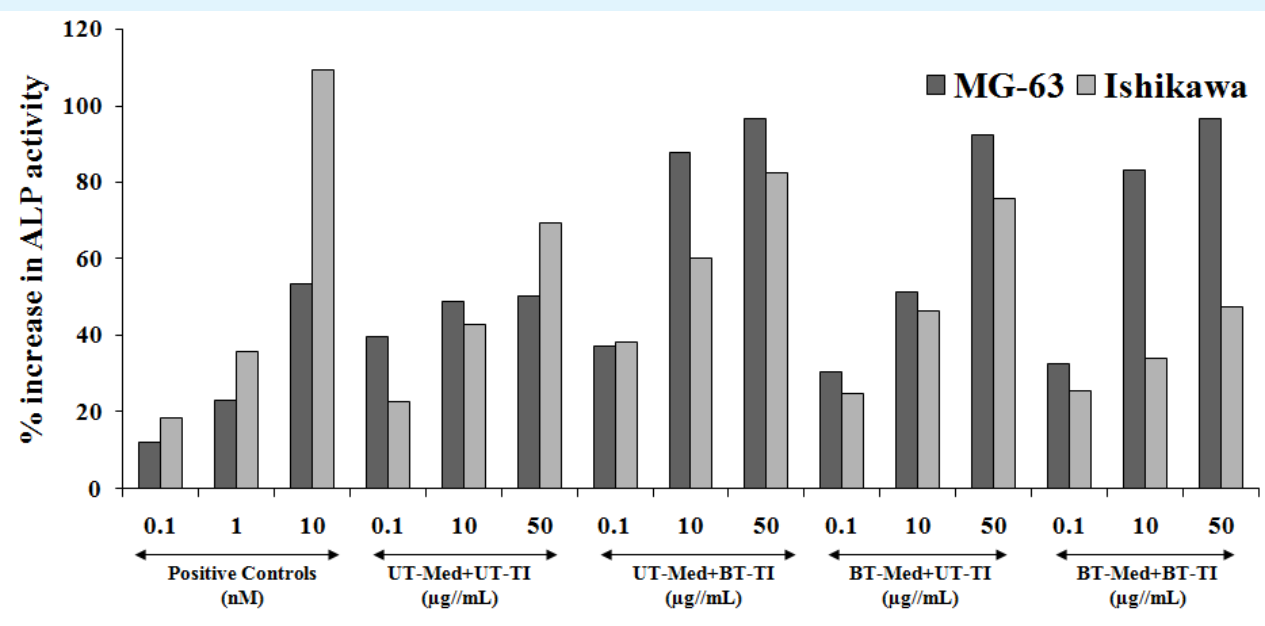

Figure 2: Alkaline phosphatase (ALP) activity in human bone osteosarcoma cells (MG-63) and human endometrial adenocarcinoma cells (Ishikawa) after treatment of the test formulation. Calcitriol and naringenin were used as positive control in MG-63 and Ishikawa cells, respectively. UT: Untreated; Med: Medium; BT: Biofield Treated; TI: Test item. 
However, the experimental test groups showed maximum increased ALP activity by $68.4 \%, 41.1 \%$, and $18.8 \%$ at $0.1,10$, and $50 \mu \mathrm{g} / \mathrm{mL}$ respectively, in the UT Med + BT-TI, while 9.6\%, 8.2\%, and 9.2\% increased ALP activity at $0.1,10$, and $50 \mu \mathrm{g} / \mathrm{mL}$ respectively, in the BTMed + UT-TI group, and 12.3\% improved ALP level was found at $0.1 \mu \mathrm{g} / \mathrm{mL}$ in the BT-Med + BT-TI group as compared to the UT-Med + UT-TI group in Ishikawa cells. Similarly, calcitriol was used as positive control for MG-63 cells, and the data showed significant improved level of ALP by $12 \%, 23 \%$, and $53.5 \%$ at $0.1,1$, and $10 \mathrm{nM}$, respectively. In the experimental tested group of MG-63 cells, the ALP percent was significantly increased by $79.5 \%$ and $92.7 \%$ at 10 and $50 \mu \mathrm{g} / \mathrm{mL}$, respectively in the UT-Med + BT-TI group as compared to the UT-Med + UTTI group. Similarly, ALP percent was significantly increased by $5.1 \%$ and $84.5 \%$ at 10 and $50 \mu \mathrm{g} / \mathrm{mL}$, respectively in the BT-Med + UT-TI group as compared to the UT-Med + UT-TI group. However, ALP percent was significantly increased by $69.8 \%$ and $93.2 \%$ at 10 and 50 $\mu \mathrm{g} / \mathrm{mL}$, respectively in the BT-Med + BT-TI group as compared to the UT-Med + UT-TI group in the MG-63 cells. Overall, it can be concluded that after treatment with the Biofield Energy Healing Treatment significant level of ALP was increased. Thus, Biofield Energy Treated Test formulation would be highly recommended option in various bone disorders without any adverse effects.

\section{Lactate Dehydrogenase (LDH) Activity in Human Cardiac Fibroblasts (HCF)}

LDH is an enzyme found in all the living cells and found to be responsible for anaerobic cellular respiration. LDH is extensively expressed in most of the body tissues, such as blood cells, skeletal muscle, and heart muscle and play a vital role in tissue injury, necrosis, hypoxia, hemolysis, or malignancies. LDH is one of the ideal biomarker for heart disease or tissue injuries [50]. LDH activity was estimated in HCF cells, and the data was presented as increased HCF cellular protection, which represents decreased LDH activity in various groups. The effect of test formulation in different groups with respect to the percent protection of HCF cells in terms of decreased level of lactate dehydrogenase (LDH) activity is presented in the Figure 3.

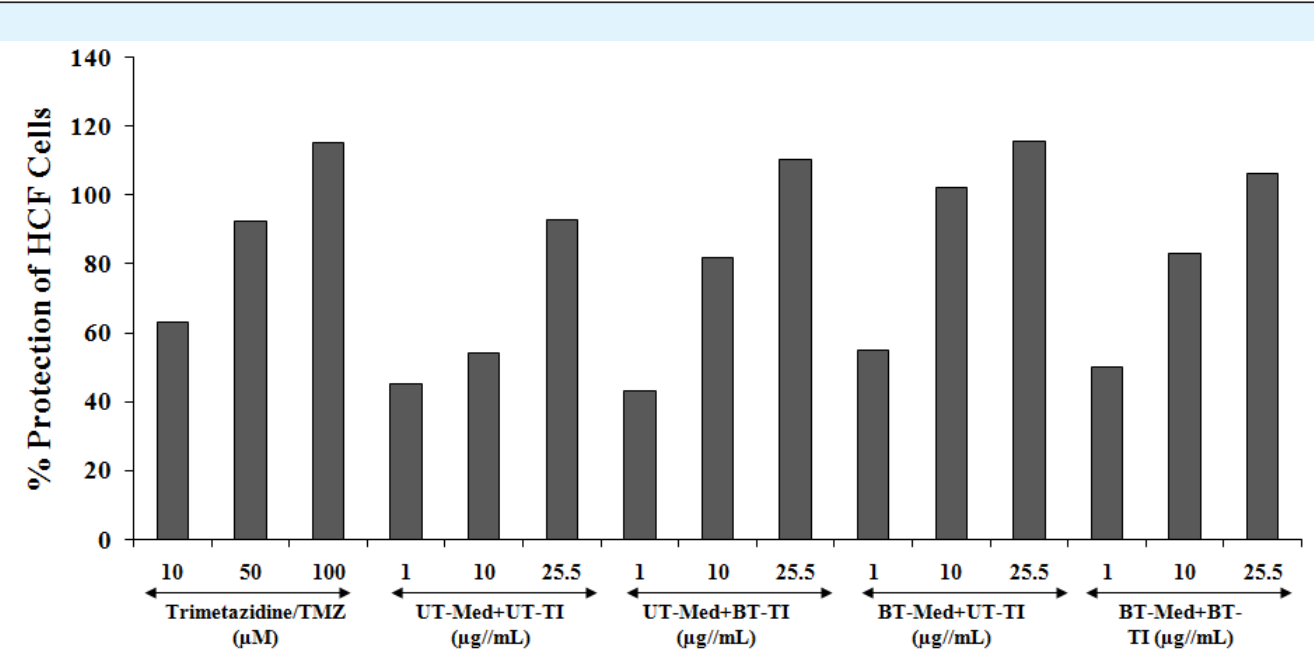

Figure 3: The effect of the test formulation on the increased percent protection of HCF cells (i.e. decreased lactate dehydrogenase) activity against tert-butyl hydroperoxide ( $t$-BHP) induced damage. TMZ: Trimetazidine; UT: Untreated; Med: Medium; BT: Biofield Treated; TI: Test item.

The positive control, trimetazidine (TMZ) showed $63.1 \%, 92.3 \%$, and $115.2 \%$ increased cellular protection of HCF cells (decreased of LDH activity) at 10, 50, and 100 $\mu \mathrm{M}$ concentration as compared to the $t$-BHP group. The test formulation showed maximum percent protection of HCF cells (decreased of LDH activity), which was significantly increased by $51.6 \%$ and $19 \%$ at 10 and 25.5 $\mu \mathrm{g} / \mathrm{mL}$ concentrations respectively, in the UT-Med + BTTI group, while $21.1 \%, 88.7 \%$, and $24.5 \%$ improved cellular protection (decreased of LDH activity) at 1, 10, and $25.5 \mu \mathrm{g} / \mathrm{mL}$ respectively, in the BT-Med + UT-TI group, and $10.8 \%, 53.7 \%$, and $14.6 \%$ improved cellular protection (decreased of LDH activity) at 1, 10, and 25.5 $\mu \mathrm{g} / \mathrm{mL}$ respectively, in BT-Med + BT-TI group as 
compared to the UT-Med + UT-TI group. Thus, the results suggested that significant reduced level of LDH activity in term of percentage cellular protection after treatment with the test formulation. LDH activity can be best depicted using HCF cells, as these cells play a central role in the extracellular matrix maintenance of the normal heart functioning [51,52]. Thus, overall data suggested that LDH activity using HCF cells was significantly reduction after Biofield Energy Treatment that could be useful against various pathological conditions such as tissue injury, necrosis, hypoxia, hemolysis or malignancies.

\section{Estimation of Alanine Amino Transferase (ALT) Activity in HepG2 Cells}

ALT is one of the important liver health enzymes and its alteration may results in hepatocellular injury and death. ALT is also present in kidney, heart, and muscles along with liver [53]. High level of ALT enzyme may results in decreased cell viability and cell death [54]. ALT activity was estimated using HepG 2 cell and the results are presented in terms of increased percentage cellular protection (represents decreased ALT activity) in the Figure 4. The positive control, silymarin was in HepG2 cells for ALT activity and the data suggested increased percentage cellular protection of HepG2 cell (decreased ALT activity) by $40.2 \%, 63.4 \%$, and $103.7 \%$ at 5,10 , and $25 \mu \mathrm{g} / \mathrm{mL}$ concentrations, respectively. Similarly, the test formulation groups showed improved cellular protection of HepG2 cells (i.e. decreased of ALT activity) by $27.7 \%$, $33 \%$, and $10.3 \%$ at $10,25.5$, and $63.75 \mu \mathrm{g} / \mathrm{mL}$ respectively, in the UT-Med + BT-TI group, while increased cellular protection of HepG2 cells (decreased of ALT activity) by $15.5 \%, 90.2 \%$, and $57.1 \%$ at $10,25.5$, and $63.75 \mu \mathrm{g} / \mathrm{mL}$ respectively, in the BT-Med + UT-TI group, and increased cellular protection of HepG2 cells (decreased of ALT activity) by $72.1 \%$ and $70.2 \%$ at 25.5 and $63.75 \mu \mathrm{g} / \mathrm{mL}$ respectively, in the BT-Med + BT-TI group as compared to the UT-Med + UT-TI group (Figure 4). Overall, the data of this activity showed that Biofield Energy Treatment significantly improved the cellular protection with reduced ALT enzyme, which suggests its application in the liver cancer, liver cirrhosis, hepatomegaly, liver failure, and hepatitis.

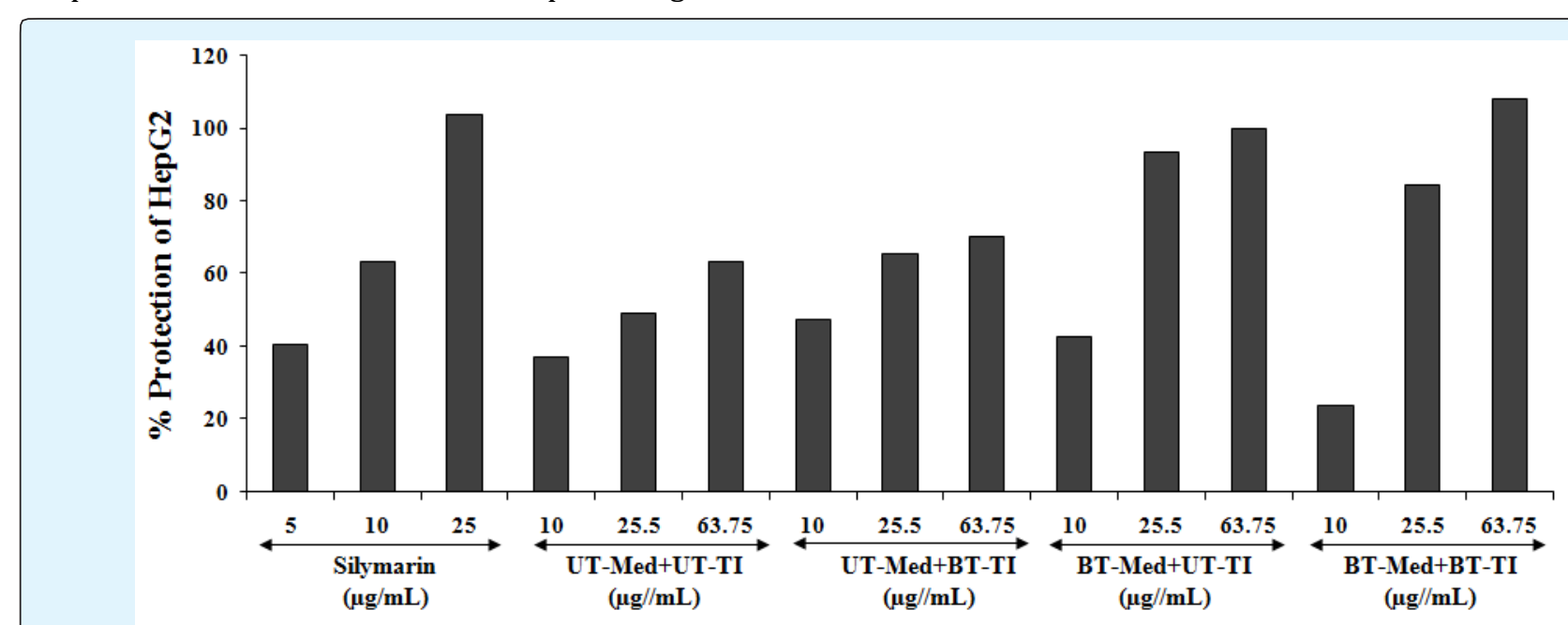

Figure 4: Increased percentage protection of liver cells (HepG2) representing decreased (ALT) Alanine amino transaminase activity under the stimulation of tert-butyl hydroperoxide ( $t$-BHP). UT: Untreated; Med: Medium; BT: Biofield Treated; TI: Test item.

\section{Superoxide Dismutase (SOD) Activity in Adenocarcinomic Human Alveolar Basal Epithelial Cells (A549)}

SOD is one of the best antioxidant defense systems in nearly all living cells that are exposed to oxygen. It also prevents the cellular damage against various types of stress and free radicals, which results in cell death [55]. The SOD activity was estimated using A549 cells and improved activity represents the increased cellular protection (Figure 5). The positive control, quercetin showed improved percentage of SOD activity with respect to the $t$-BHP by $68.4 \%, 3.9 \%$, and $104.2 \%$ at 10,25 , and $50 \mu \mathrm{g} / \mathrm{mL}$ concentration respectively. However, the percent protection of A549 (lungs) cells (increased of SOD activity) was significantly increased by $5.5 \%$ and $21.5 \%$ at 1 and $25.5 \mu \mathrm{g} / \mathrm{mL}$ respectively, in the UT-Med + BT-TI group, while increased SOD activity by $33.4 \%, 25.8 \%$, and 
$21.5 \%$ at 1,10 , and $25.5 \mu \mathrm{g} / \mathrm{mL}$ respectively, in the BTMed + UT-TI group, and increased SOD activity by $5.5 \%$ and $12.8 \%$ at 1 and $25.5 \mu \mathrm{g} / \mathrm{mL}$ respectively, in the BTMed + BT-TI group as compared to the UT-Med + UT-TI group(Figure 5). Overall, the experimental data revealed that the Biofield Energy Treatment has significantly improved the SOD antioxidant defense activity, which could protect from many respiratory diseases such as Alzheimer's disease, pneumonia, asthma, Down's syndrome, familial amyotrophic lateral sclerosis (FALS), Parkinson's disease, dengue fever, cancer, cataract, and several neurological disorders.

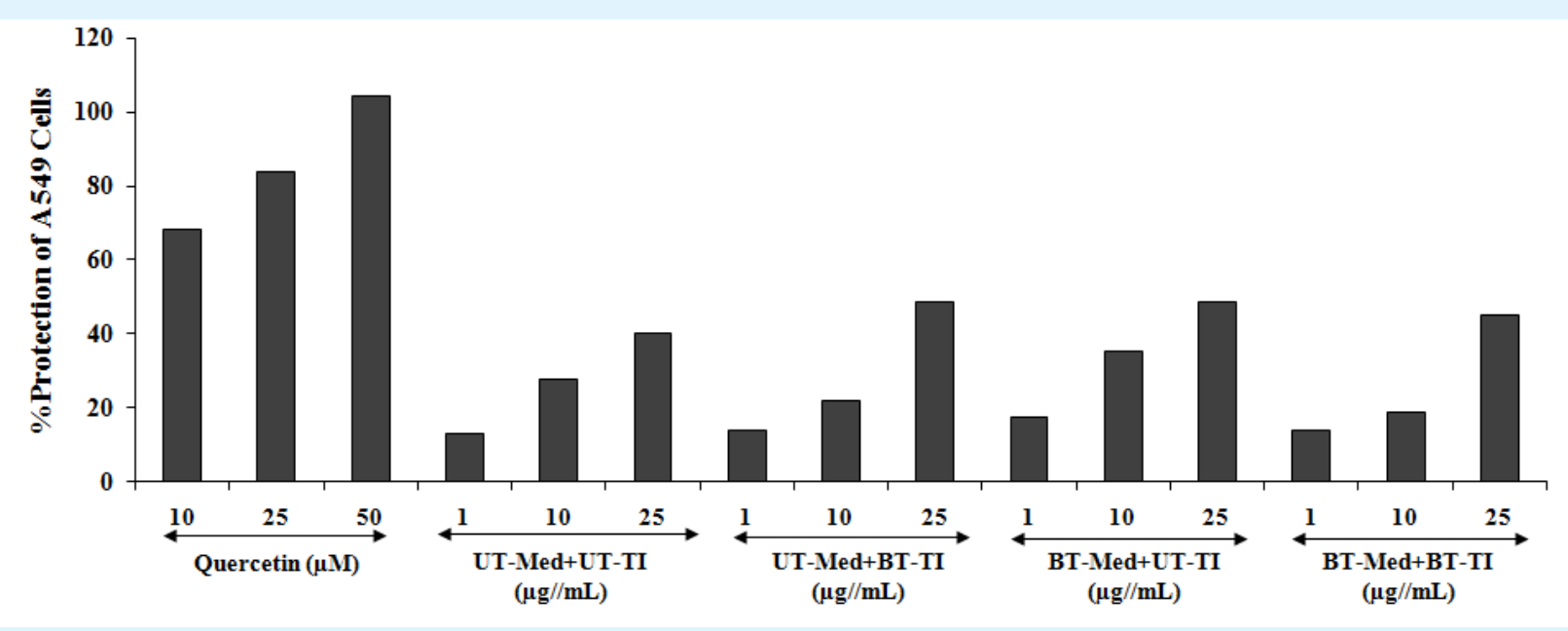

Figure 5: Percent cellular protection of lungs cells (A549) in terms of increased SOD activity under the stimulation of tert-butyl hydroperoxide ( $t$-BHP). UT: Untreated; Med: Medium; BT: Biofield Treated; TI: Test item.

\section{Estimation of Serotonin Level In Human Neuroblastoma (SH-SY5Y) cells}

Serotonin assay was performed using SH-SY5Y cells and the effect of test formulation was assessed after 24 hours of treatment using ELISA assay. Low level of serotonin represents depression because it is important neurotransmitter. In addition, it is supposed to be responsible for many neuropsychiatric disorders (viz. Alzheimer's disease, cognitive health, loss of ability of thinking, depression, memory loss, etc.) along with various neuronal disorders like sleep, feeding, pain, sexual behavior, cardiac regulation, and cognition [56]. Serotonin activity was tested and the data is presented in the Figure 6.

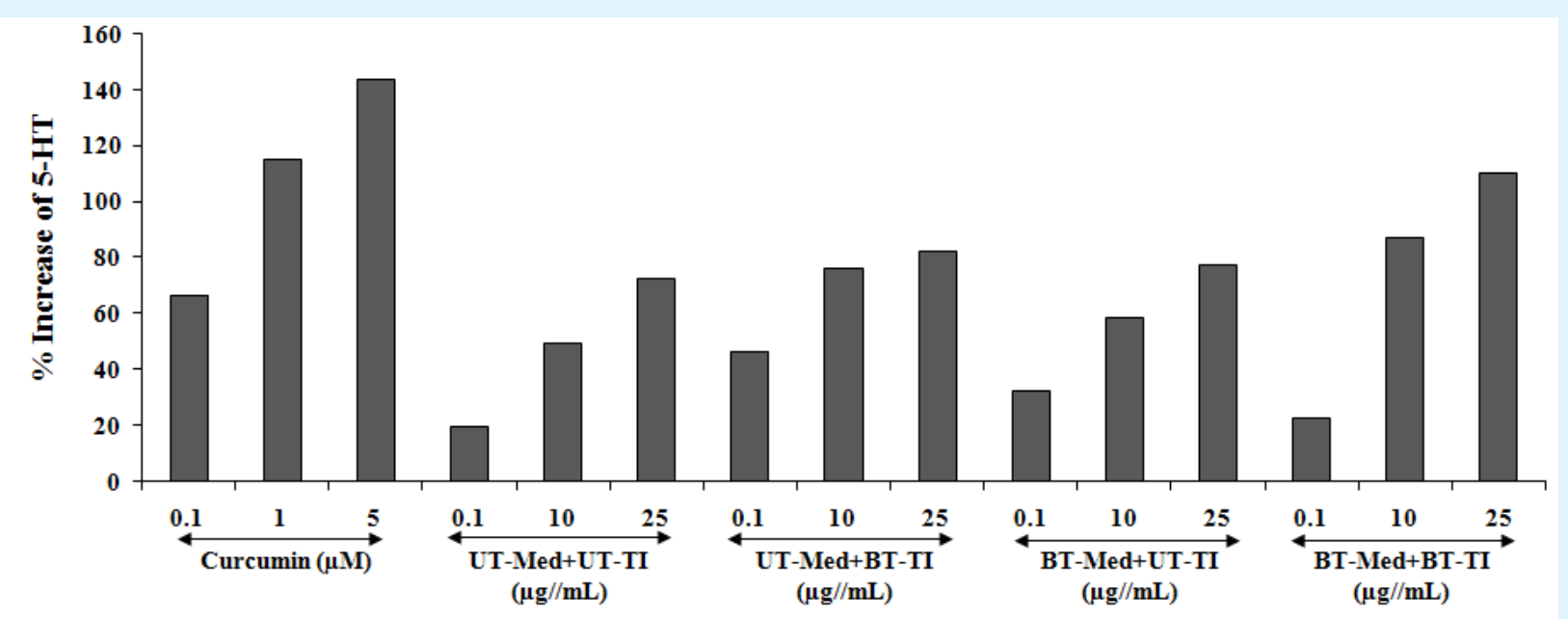

Figure 6: The effect of the test formulation on percent increase in 5-hydroxy tryptamine (5-HT) in human neuroblastoma cells (SH-SY5Y). UT: Untreated; Med: Medium; BT: Biofield Treated; TI: Test item. 
Curcumin was used a positive control, showed $66.3 \%$, $115.1 \%$, and $143.4 \%$ increased level of serotonin at $0.1,1$, and $5 \mu \mathrm{g} / \mathrm{mL}$ respectively, compared to the vehicle control (VC) group. The experimental data showed significant increased serotonin level by $137.4 \%, 5.1 \%$, and $13 \%$ at $0.1,10$, and $25 \mu \mathrm{g} / \mathrm{mL}$ respectively, in the UTMed + BT-TI, while significant increased serotonin by $65.4 \%, 18.8 \%$, and $6.4 \%$ at $0.1,10$, and $25 \mu \mathrm{g} / \mathrm{mL}$ respectively, in the BT-Med + UT-TI, and $16.9 \%, 77.3 \%$, and $51.8 \%$ improved serotonin level at $0.1,10$, and 25 $\mu \mathrm{g} / \mathrm{mL}$ respectively, in the BT-Med + BT-TI group as compared to the UT-Med + UT-TI group (Figure 6). Thus, serotonin level was significantly improved in the entire tested group. Our data revealed significant improved level of serotonin after treatment with the Biofield Energy Healing Treated test formulation that would be highly useful against various neurodegenerative diseases, improved brain functioning, social behavior, appetite and digestion, sleep, memory, sexual desire, and associated functions.

\section{Effect of Test Formulation on Vitamin D Receptors (VDRs) in MG-63 Cells}

Human bone osteosarcoma cells (MG-63) was used for the estimation of VDR activity. VDR expression was studies using ligand binding through vitamin $\mathrm{D}$ active molecule, which was estimated using quantitativepolymerase chain reaction (qPCR) amplification. With the use of real time PCR, different VDR-relative threshold cycle $\left(\mathrm{VDR}-\mathrm{C}_{\mathrm{T}}\right)$ values were obtained after complete amplification cycles using specific primer probes. Relative quantification (RQ) was calculated from the VDR- $C_{T}$ and house-keeping (HK)- $\mathrm{C}_{\mathrm{T}}$ values in MG-63 cells. The values after treated with the Biofield Energy Treated and untreated test formulation and positive control are represented in the Figure 7. Calcitriol was used as a positive control and the RQ of VDR was found to be increased in concentration-dependent manner by $55.8 \%$, $65.9 \%$, and $109.9 \%$ at $0.1,1$, and $10 \mathrm{nM}$, respectively. The experimental test groups showed increased RQ of VDR expression by $24.2 \%$ and $4.4 \%$ in the UT-Med + BT-TI group at 1 and $50 \mu \mathrm{g} / \mathrm{mL}$ respectively, while $64.9 \%$, $213.7 \%$, and $127 \%$ increased RQ of VDR at 1,10 , and 50 $\mu \mathrm{g} / \mathrm{mL}$ respectively, in the BT-Med + UT-TI group, and increased RQ of VDR by $166.6 \%, 328.7 \%$, and $205.1 \%$ at 1,10 and $50 \mu \mathrm{g} / \mathrm{mL}$ respectively, in the BT-Med + BT-TI group as compared to the UT-Med + UT-TI group. Calcitriol was reported to bind with the VDRs and extensively regulates the calcium homeostasis, immunity, overall cellular growth, and differentiation [57]. Calcitriol controls various calcium metabolisms and play a vital role in improving quality of life and overall bone cell growth and development [58,59]. In conclusion, VDR expression was significantly improved in MG-63 after treatment with the Trivedi Effect ${ }^{\circledR}$, which could be the best alternative treatment approach for bone related disorders.

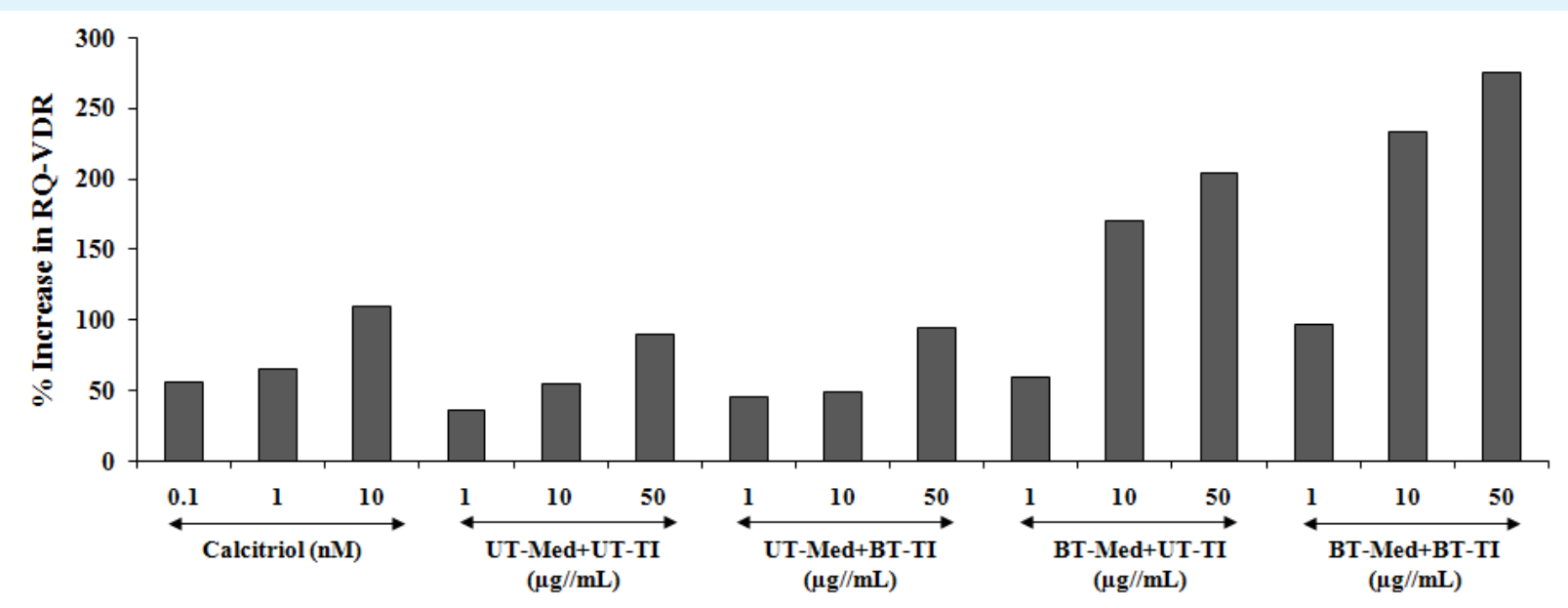

Figure 7: Relative quantification (RQ) of vitamin D receptors (VDRs) gene in human bone osteosarcoma cells (MG63).UT: Untreated; Med: Medium; BT: Biofield Treated; TI: Test item.

\section{Conclusion}

MTT assay was used for estimation of safe concentrations of the test formulation and results showed that the test formulation was found safe and non-toxic against all the tested cell lines. Cytoprotective activity against $t$-BHP induced cell damage was tested using human cardiac fibroblasts cells (HCF), which showed 
restoration of cell viability by $105.4 \%$ (at $25 \mu \mathrm{g} / \mathrm{mL}$ ), $32.8 \%$ (at $25 \mu \mathrm{g} / \mathrm{mL}$ ), and $151.8 \%$ (at $10 \mu \mathrm{g} / \mathrm{mL}$ ) in the UT-Med + BT-TI, BT-Med + UT-TI, BT-Med + BT-TI groups respectively, as compared to the untreated test group, while in HepG2 cells the maximum restoration of cell viability was by $22.4 \%$ (at $25.5 \mu \mathrm{g} / \mathrm{mL}$ ), $67.1 \%$ (at 10 $\mu \mathrm{g} / \mathrm{mL}$ ), and $72.9 \%$ (at $10 \mu \mathrm{g} / \mathrm{mL}$ ) in the UT-Med + BT-TI, BT-Med + UT-TI, BT-Med + BT-TI groups respectively, as compared to the untreated test group. In A549 cells, cellular restoration was improved by $70.4 \%$, and $14.1 \%$ at 1 and $25.5 \mu \mathrm{g} / \mathrm{mL}$ respectively, in the BT-Med + UT-TI group, while $3 \%$ and $4.6 \%$ improved cellular restoration was reported at 10 and $25.5 \mu \mathrm{g} / \mathrm{mL}$ respectively, at BTMed + BT-TI groups as compared to the untreated test group. Similarly, ALP activity in Ishikawa cells showed significantly increased ALP activity by $68.4 \%, 9.6 \%$, and $12.3 \%$ in the UT-Med + BT-TI, BT-Med + UT-TI group, and BT-Med + BT-TI groups respectively, at $0.1 \mu \mathrm{g} / \mathrm{mL}$ as compared to the untreated test group. Similarly, ALP activity in MG-63 cells with maximum cellular protection was reported at $50 \mu \mathrm{g} / \mathrm{mL}$ by $92.7 \%, 84.5 \%$, and $93.2 \%$ in the UT-Med + BT-TI, BT-Med + UT-TI, and BT-Med + BTTI group test groups, respectively, as compared with the untreated test group. LDH activity was significantly decreased and the data was presented in increased percentage cellular protection data, which showed maximum cellular protection at $10 \mu \mathrm{g} / \mathrm{mL}$ concentration by $51.6 \%, 88.7 \%$, and $53.7 \%$ in the UT-Med + BT-TI, BTMed + UT-TI group, and BT-Med + BT-TI groups respectively, as compared to the untreated test group. ALT activity showed maximum improved cellular protection of HepG2 cells (decreased of ALT activity) by $33 \%, 90.2 \%$, and $72.1 \%$ at $25.5 \mu \mathrm{g} / \mathrm{mL}$ in the UT-Med + BT-TI, BT-Med + UT-TI group, and BT-Med + BT-TI groups respectively, as compared with the untreated test group. SOD activity was significantly increased by $21.5 \%$ (at 25.5 $\mu \mathrm{g} / \mathrm{mL}$ ), $33.4 \%$ (at $1 \mu \mathrm{g} / \mathrm{mL}$ ), and $12.8 \%$ (at $25.5 \mu \mathrm{g} / \mathrm{mL}$ ) in the UT-Med + BT-TI, BT-Med + UT-TI group, and BTMed + BT-TI groups respectively, as compared with the untreated test group. Serotonin level was significantly increased in SH-SY5Y cells by $137.4 \%$ (at $0.1 \mu \mathrm{g} / \mathrm{mL}$ ), $65.4 \%$ (at $0.1 \mu \mathrm{g} / \mathrm{mL}$ ), and $77.3 \%$ (at $10 \mu \mathrm{g} / \mathrm{mL}$ ) in the UT-Med + BT-TI, BT-Med + UT-TI, and BT-Med + BT-TI groups respectively, as compared with the untreated test group. VDR expression was tested in MG-63 cells, which showed increased RQ of VDR by $24.2 \%$ at $1 \mu \mathrm{g} / \mathrm{mL}$ in the UT-Med + BT-TI group, while 64.9\%, 213.7\%, and $127 \%$ increased RQ of VDR at 1,10 , and $50 \mu \mathrm{g} / \mathrm{mL}$ respectively in the BT-Med + UT-TI group, and $166.6 \%, 328.7 \%$, and $205.1 \%$ increased RQ of VDR at 1,10 and $50 \mu \mathrm{g} / \mathrm{mL}$ respectively, in the BT-Med + BT-TI groups as compared to the untreated test control group. Thus, it can be concluded that Biofield Energy Treatment (The Trivedi Effect ${ }^{\circledR}$ ) can be used for the prevention of various types of cardiac disorders such as stroke, thromboembolic disease, congestive heart failure, congenital heart disease, peripheral artery disease, rheumatic heart disease, valvular heart disease, and venous thrombosis, etc. Biofield Energy based test formulation can improve the overall functioning of heart, liver, bones, neuronal, and lungs parameters against wide range of oxidative stress or damage induced by free radicals. In addition, it would also protect against many hepatic disorders (cirrhosis, liver cancer, hemochromatosis, and Wilson disease), lungs disorders (asthma, chronic bronchitis, emphysema, cystic fibrosis, and pneumonia), and many immune disorders. In addition, this novel test formulation can also be utilized for organ transplants (i.e., kidney, liver, and heart transplants), hormonal imbalance, aging, and various inflammatory and immune-related disease conditions like Asthma, Aplastic Anemia, Graves' Disease, Dermatitis, Diabetes, Parkinson's Disease, Myasthenia Gravis, Ulcerative Colitis (UC), Atherosclerosis, etc. to improve overall health and Quality of Life.

\section{Acknowledgement}

Authors gratefully acknowledged to Trivedi Global, Inc., Trivedi Science, and Trivedi Master Wellness for their support. In addition, authors are thankful for the support of Dabur Research Foundation for conducting this study.

\section{Conflicts of Interest}

The authors declare no conflicts of interest.

\section{References}

1. WHO (2004) WHO Guidelines on Safety Monitoring of Herbal Medicines in Pharmacovigilance Systems. World Health Organization, Geneva, Switzerland.

2. Bandaranayake WM (2006) Quality control, screening, toxicity and regulation of herbal drugs, in Modern Phytomedicine. In: Ahmad I, Aqil F, Owais M, (Eds.), Turning Medicinal Plants into Drugs, Weinheim:Wiley-VCH GmbH \& Co. KGaA, pp: 25-57.

3. Ryan-Harshman M, Aldoori W (2005) Health benefits of selected minerals. Can Fam Physician 51(5): 673675.

4. Rayman MP (2000) The importance of selenium to human health. Lancet 356(9225): 233-241.

5. Beard JL, Connor JR (2003) Iron status and neural functioning. Ann Rev Nutr 23: 41-58. 
6. Coleman CI, Hebert JH, Reddy P (2003) The effects of Panax ginseng on quality of life. J Clin Pharm Ther 28(1): 5-15.

7. Das L, Bhaumik E, Raychaudhuri U, Chakraborty R (2011) Role of nutraceuticals in human health. J Food Sci Technol 49(2): 173-183.

8. Czekanska EM, Stoddart MJ, Richards RG, Hayes JS (2012) In search of an osteoblast cell model for in vitro research. Eur Cell Mater 24: 1-17.

9. Schaefer WR, Fischer L, Deppert WR, Hanjalic Beck A, Seebacher L, et al. (2010) In vitro-Ishikawa cell test for assessing tissue-specific chemical effects on human endometrium. Reprod Toxicol 30(1): 89-93.

10. Valavanidis A, Vlachogianni T, Fiotakis K, Loridas $S$ (2013) Pulmonary Oxidative Stress, Inflammation and Cancer: Respirable Particulate Matter, Fibrous Dusts and Ozone as Major Causes of Lung Carcinogenesis through Reactive Oxygen Species Mechanisms. Int J Environ Res Public Health 10(9): 3886-3907.

11. Bouma ME, Rogier E, Verthier N, Labarre C, Feldmann G (1989) Further cellular investigation of the human hepatoblastoma-derived cell line HepG2: Morphology and immunocytochemical studies of hepatic-secreted proteins. In Vitro Cell Dev Biol 25(3): 267-75.

12. Bak MJ, Jun M, Jeong WS (2012) Antioxidant and hepatoprotective effects of the red ginseng essential oil in $\mathrm{H}(2) \mathrm{O}(2)$-treated hepG2 cells and $\mathrm{CCl}(4)$ treated mice. Int J Mol Sci 13(2): 2314-2330.

13. Molavi B, Mehta JL (2004) Oxidative stress in cardiovascular disease: molecular basis of its deleterious effects, its detection, and therapeutic considerations. Curr Opin Cardiol 19(5): 488-493.

14. Meneses A, Liy Salmeron G (2012) Serotonin and emotion, learning and memory. Rev Neurosci 23(5-6): 543-553.

15. Rohm B, Holik AK, Somoza MM, Pignitter M, Zaunschirm M, et al. (2013) Nonivamide, a capsaicin analog, increases dopamine and serotonin release in SH-SY5Y cells via a TRPV1-independent pathway. Mol Nutr Food Res 57(11): 2008-2018.

16. Haussler MR, Whitfield GK, Haussler CA, Hsieh JC, Thompson PD, et al. (1998) The nuclear vitamin D receptor: biological and molecular regulatory properties revealed. J Bone Miner Res 13(3): 325349.
17. Brown AJ, Brown AJ, Slatopolsky E (1999) Vitamin D. Am J Physiol Renal Physiol 277(2): 157-175.

18. Movaffaghi Z, Farsi M (2009) Biofield therapies: Biophysical basis and biological regulations. Complement Ther Clin Pract 15(1): 35-37.

19. Movaffaghia Z, Farsi M (2009) Biofield therapies: Biophysical basis and biological regulations. Complement Ther Clin Pract 15(1): 35-37.

20. Barnes PM, Bloom B, Nahin RL (2008) Complementary and alternative medicine use among adults and children: United States, 2007. Natl Health Stat Report 10(12): 1-23.

21. Yang P, Jiang Y, Rhea PR, Coway T, Chen D, et al. (2019) Human Biofield Therapy and the Growth of Mouse Lung Carcinoma. Integr Cancer Ther.

22. Ross CL (2019) Energy Medicine: Current Status and Future Perspectives. Glob Adv Health Med.

23. Fan K wai (2005) National Center for Complementary and Alternative Medicine Website. J Med Libr Assoc 93: 410-412.

24. Wisneski L, Anderson L (2009) The Scientific Basis of Integrative Medicine. $2^{\text {nd }}(E d n)$, Boca Raton, FL: CRC Press, pp: 205.

25. Trivedi MK, Tallapragada RM (2008) A transcendental to changing metal powder characteristics. Metal Powder Report 63(9): 22-28,31.

26. Trivedi MK, Nayak G, Patil S, Tallapragada RM, Latiyal O (2015) Studies of the atomic and crystalline characteristics of ceramic oxide nano powders after bio field treatment. Ind Eng Manage 4: 161.

27. Trivedi MK, Branton A, Trivedi D, Nayak G, Mondal SC, et al. (2015) Morphological characterization, quality, yield and DNA fingerprinting of biofield energy treated alphonso mango (Mangifera indica L.). Journal of Food and Nutrition Sciences 3(6): 245-250.

28. Trivedi MK, Branton A, Trivedi D, Nayak G, Charan S, et al. (2015) Phenotyping and 16S rDNA analysis after biofield treatment on Citrobacter braakii: A urinary pathogen. J Clin Med Genom 3: 129.

29. Trivedi MK, Patil S, Shettigar H, Mondal SC, Jana S (2015) Evaluation of biofield modality on viral load of Hepatitis B and C viruses. J Antivir Antiretrovir 7: 8388. 
30. Trivedi MK, Patil S, Shettigar H, Bairwa K, Jana S (2015) Phenotypic and biotypic characterization of Klebsiella oxytoca: An impact of biofield treatment. J Microb Biochem Technol 7: 203-206.

31. Nayak G, Altekar N (2015) Effect of biofield treatment on plant growth and adaptation. J Environ Health Sci 1(2): 1-9.

32. Branton A, Jana S (2017) The influence of energy of consciousness healing treatment on low bioavailable resveratrol in male Sprague Dawley rats. International Journal of Clinical and Developmental Anatomy 3: 9-15.

33. Branton A, Jana S (2017) The use of novel and unique biofield energy healing treatment for the improvement of poorly bioavailable compound, berberine in male Sprague Dawley rats. American Journal of Clinical and Experimental Medicine 5(4): 138-144.

34. Kinney JP, Trivedi MK, Branton A, Trivedi D, Nayak G, et al. (2017) Overall skin health potential of the biofield energy healing based herbomineral formulation using various skin parameters. American Journal of Life Sciences 5(2): 65-74.

35. Singh J, Trivedi MK, Branton A, Trivedi D, Nayak G, et al. (2017) Consciousness energy healing treatment based herbomineral formulation: A safe and effective approach for skin health. American Journal of Pharmacology and Phytotherapy 2(1): 1-10.

36. Trivedi MK, Branton A, Trivedi D, Nayak G, Plikerd WD, et al. (2017) A Systematic study of the biofield energy healing treatment on physicochemical, thermal, structural, and behavioral properties of magnesium gluconate. International Journal of Bioorganic Chemistry 2(3): 135-145.

37. Trivedi MK, Patil S, Shettigar H, Mondal SC, Jana S (2015) The potential impact of biofield treatment on human brain tumor cells: A time-lapse video microscopy. J Integr Oncol 4(3): 141.

38. Anagnos D, Trivedi K, Branton A, Trivedi D, Nayak G, et al. (2018) Influence of biofield treated vitamin $\mathrm{D}_{3}$ on proliferation, differentiation, and maturation of bone-related parameters in MG-63 cell-line. International Journal of Biomedical Engineering and Clinical Science 4(1): 6-14.

39. Lee AC, Trivedi K, Branton A, Trivedi D, Nayak G, et al. (2018) The potential benefits of biofield energy treated vitamin D3 on bone mineralization in human bone osteosarcoma cells (MG-63). International Journal of Nutrition and Food Sciences 7(1): 30-38.

40. Stutheit ME, Trivedi K, Branton A, Trivedi D, Nayak G, et al. (2018) Biofield energy treated vitamin D3: Therapeutic implication on bone health using osteoblasts cells. American Journal of Life Sciences 6(1): 13-21.

41. Alia M, Ramos S, Mateos R, Bravo L, Goya L (2005) Response of the antioxidant defense system to tertbutyl hydroperoxide and hydrogen peroxide in a human hepatoma cell line (HepG2). J Biochem Mol Toxicol 19(2): 119-128.

42. Mendoza NV, Santillan EM, Gonzalez AM, Soto JE, Chirino CE, et al. (2014) Hepatoprotective effect of silymarin. World J Hepatol 6: 144-149.

43. Alia M, Ramos S, Mateos R, Bravo L, Goya L (2005) Response of the antioxidant defense system to tertbutyl hydroperoxide and hydrogen peroxide in a human hepatoma cell line (HepG2). J Biochem Mol Toxicol 19(2): 119-128.

44. Videla LA (2009) Oxidative stress signaling underlying liver disease and hepatoprotective mechanisms. World J Hepatol 1(1): 72-78.

45. Li S, Tan HY, Wang N, Zhang ZJ, Lao L, et al. (2015) The role of oxidative stress and antioxidants in liver diseases. Int J Mol Sci 16(11): 26087-26124.

46. Cheresh P, Kim SJ, Tulasiram S, Kamp DW (2013) Oxidative stress and pulmonary fibrosis. Biochim Biophys Acta 1832(7): 1028-1040.

47. Lu LY, Ou N, Lu QB (2013) Antioxidant induces DNA damage, cell death and mutagenicity in human lung and skin normal cells. Sci Rep 3: 3169.

48. Atkins GJ, Findlay DM, Anderson PH, Morris HA (2011) Vitamin D 3rd (Edn.), Vitamin D, Chapter 23Target Genes: Bone Proteins 1: 411-424.

49. Emami A, Larsson A, Petrén Mallmin M, Larsson S (1999) Serum bone markers after intramedullary fixed tibial fractures. Clin Orthop Relat Res 368: 220229.

50. Burgner JW, Ray WJ (1984) On the origin of the lactate dehydrogenase induced rate effect. Biochemistry 23: 3636-3648.

51. Valvona CJ, Fillmore HL, Nunn PB, Pilkington GJ (2016) The regulation and function of lactate 
dehydrogenase A: Therapeutic potential in brain tumor. Brain Pathol 26(1): 3-17.

52. Kopperschläger G, Kirchberger J (1996) Methods for the separation of lactate dehydrogenases and clinical significance of the enzyme. J Chromatogr B Biomed Appl 684(1-2): 25-49.

53. Pratt DS, Kaplan MM (2000) Evaluation of abnormal liver-enzyme results in asymptomatic patients. N Engl J Med 342(17): 1266-1271.

54. Mathiesen U, Franzen L, Fryden A, Foberg U, Bodemar G (1999) The clinical significance of slightly to moderately increased liver transaminase values in asymptomatic patients. Scand J Gastroenterol 34(1): 85-91.

55. Birben E, Sahiner UM, Sackesen C, Erzurum S, Kalayci O (2012) Oxidative stress and antioxidant defense. World Allergy Organ J 5(1): 9-19.
56. Meltzer CC, Smith G, DeKosky ST, Pollock BG, Mathis CA, et al. (1998) Serotonin in aging, late-life depression, and Alzheimer's disease: the emerging role of functional imaging. Neuropsychopharmacology 18(6): 407-430.

57. Haussler MR, Whitfield GK, Haussler CA, Hsieh JC, Thompson PD, et al. (1998) The nuclear vitamin D receptor: biological and molecular regulatory properties revealed. J Bone Miner Res 13(3): 325349.

58. Hollis BW (2005) Circulating 25-hydroxyvitamin D levels indicative of vitamin D sufficiency: implications for establishing a new effective dietary intake recommendation for vitamin D. J Nutr 135(2): 317322.

59. Carlberg C, Molnár F (2012) Current status of vitamin D signaling and its therapeutic applications. Curr Top Med Chem 12(6): 528-547. 